\title{
PEMANFAATAN TEKNOLOGI ELEKTRIFIKASI PADA ALAT GALI MUAT OPERASIONAL PENAMBANGAN
}

\author{
Ahmad Zaki Romi ${ }^{1}$, Robbi Hidayat ${ }^{2}$, Okta Robian Pranata ${ }^{1}$, Desliwandi ${ }^{2}$ \\ ${ }^{1}$ Evalusi dan Optimasi, Penambangan Swakelola, PT. Bukit Asam, Tbk \\ ${ }^{2}$ Penambangan Elektrifikasi, Penambangan Swakelola, PT. Bukit Asam, Tbk
}

\begin{abstract}
ABSTRAK
Kondisi perekonomian global yang kurang baik menjadikan harga batubara cenderung terus menurun. Perseroan telah merespon dengan cepat kondisi tersebut dengan meningkatkan efisiensi operasional, pengendalian biaya, melakukan diversifikasi pemasaran ekspor termasuk mengintrodusir pola penambangan terfokus. Salah satu program efisiensi operasional untuk pengendalian biaya dan Pengembangan perusahaan adalah Program Elektrifikasi dimana sebelumnya operasional penambangan didominasi dengan sistem penambangan berbasis BBM. Implementasi Sistem Penambangan dengan peralatan penambangan berbasis listrik juga dirancang melalui tahapan-tahapan untuk menyesuaikan dengan target perusahaan jangka pendek dan jangka panjang serta menyesuaikan dengan kesiapan peralatan. Kebutuhan rencana produksi yang terus meningkat berdasarkan rencana jangka panjang perusahaan, dari hasil kajian diperoleh penambahan produksi secara swakelola dengan investasi peralatana tambang berbasis listrik. Pada bulan Agustus tahun 2017 PT. Bukit Asam, Tbk telah melakukan kegiatan operasional penambangan menggunakan alat gali muat dengan electric shovel di Pit 2 dan Pit 3 pada lokasi IUP Banko Barat. Penggunaan alat gali muat electric shovel dapat meningkatkan efisiensi operasional dan pengendalian biaya operasional.
\end{abstract}

\section{A. LATAR BELAKANG}

Dengan semakin terbatasnya sumber energy berbasis bahan bakar minyak dunia, berbanding terbalik dengan kebutuhan BBM yang terus meningkat dan mengakibatkan kecenderungan harga bbm terus mengalami peningkatan sehingga biaya produksi tinggi di sektor ekonomi tidak bisa dihindari. Sehingga berdampak pada penurunan permintyaan batubara, dan meningkatnya persaingan serta turunnya harga batubara di pasar global maupun di pasar domestik. Peningkatan produksi batubara secara global serta perubahan kebijakan penggunaan energy berbasis batubara di beberapa Negara konsumen menjadikan harga batubara cenderung terus menurun.

Perseroan terlah merespon dengan cepat kondisi tersebut dengan meningkatkan efisiensi operasional, mengendalikan biaya, melakukan diversifikasi pemasaran ekspor termasuk mengintrodusir pola penambangan terfokus. Salah satu program efisiensi operasional untuk pengendalian biaya dan pengembangan perusahaan adalah Program Elektrifikasi untuk pemilihan metoda penambangan maupun pemilihan peralatan tambang baru, dimana sebelumnya operasional penambangan didominasi dengan sistem penambangan berbasis BBM dengan menggunakan metoda/peralatan tambang konvensional (shovel and truck). Dalam RJPP PTBA ditargetkan peningkatan produksi dan penghematan biaya produksi mininmal rata-rata $10 \%$ per tahun dalam waktu lima tahun kedepan.

Untuk merealisasikan rencana tersebut opsi peningkatan produksi secara swakelola dengan dukungan metode dan peralatan yang efisien dengan memanfaatkan potensi sumber daya internal. Dimana kendala kompetensi serta tuntutan fleisibelitas alternative rencana metode dan peralatan yang efisien merupakan pertimbangan yang realistis dalam mencapai produktifitas yang tinggi dan biaya operasi yang murah. 
Dalam rangka pengembangan dimaksud Perseroan telah melakukan investasi peralatan tambang berbasis listrik dengan memanfaatkan kapasitas kompetensi dalam mengelola sistem penambangan berkelanjutan (Contimous Mining) serta potensi sumber daya internal yang sudah ada (PLTU Milik Sendiri) untuk mengurangi ketergantungan kepada konsumsi BBM dan jasa penambangan pihak III di semua wilayah IUP yang dimiliki sesuai karakter lokasi masing-masing (TAL, MTB, Banko Barat, Banko Tengah).

\section{B. PENDAHULUAN}

PT. Bukit Asam Tbk didirikan pada tanggal 2 Maret 1981 berdasarkan Peraturan Pemerintah No. 42 tahun 1980 dengan akta Notaris Mohamad Ali No. 1 yang telah diubah dengan akta Notaris No. 5 tanggal 6 Maret 1984 dan No. 51 tanggal 29 Mei 1985 dari notaris yang sama. Akta penderian dan perubahan tersebut disahkan oleh Menteri Kehakiman dalam Surat Keputusan No. C2-7553HT.01.04.TH.85 tanggal 28 November 1985 serta diumumkan dalam Berita Negara No. 33, Tambahan No. 550 tanggal 25 April 1986. Saat ini PTBA memiliki 2 (dua) unit pertambangan, yaitu Unit Penambangan Tanjung Enim yang berlokasi di Tanjung Enim, Sumatera Selatan yang merupakan penambangan Terbuka dan unit Penambangan Ombilin di Sawahlunto, Sumatera Barat, yang merupakan penambangan Bawah Tanah.

Air Laya merupakan tambang pertama yang memproduksi batubara dengan skala komersial di daerah Tanjung enim. Aktifitas pertambangan dimulai pada tahun 1919 dengan pengembangan dari tambang terbuka kecil yang dioperasikan oleh pemerintahan Belanda. Pertambangan bawah tanah dimulai pada 1923, dan berlanjut hingga 1940an. Produksi diawali tahun 1938 pada dua lokasi, mengekstraksi batubara sub-bituminus dari Air Laya Timur, dan semi-antrasit yang sekarang merupakan Suban pit.

Wilayah Tambang UPTE terletak di dekat Kota Tanjung Enim, dimana wilayah tsb. termasuk dalam wilayah Kabupaten Muara Enim dan Kabupaten Lahat, Propinsi Sumatera Selatan, Indonesia. Wilayah ini dapat ditempuh dari Jakarta dengan penerbangan reguler ke Kota Palembang, Ibukota Propinsi Sumatera Selatan. Dari Kota Palembang perjalanan dapat ditempuh dengan kendaraan roda empat melalui jalan aspal ke arah Baratdaya dengan waktu tempuh lebih kurang 6 (enam) jam atau berjarak $210 \mathrm{~km}$ hingga kota Tanjung Enim.

Gambar 2 di bawah memperlihatkan lokasi Tambang di wilayah UPTE PTBA secara regional. Gambar tersebut juga memperlihatkan sistem pengangkutan batubara yang dioperasikan oleh PT Kereta Api Indonesia (KAI); dari Kota Tanjung Enim ke Pelabuhan Kertapati, Palembang, Sumatera Selatan dan Pelabuhan Tarahan, Lampung.

\section{KEADAAN UMUM GEOLOGI BATUBARA DI WILAYAH UPTE - PTBA}

Di wilayah UPTE-PTBA dan sekitarnya, Formasi Muara Enim dijumpai secara lengkap yaitu anggota M1, M2, M3 dan M4. Anggota M1 mengandung 2 lapisan batubara yaitu BatubaraBatubara Keladi (Seam E) dan Merapi (Seam D); Anggota M2 mengandung 4 lapisan batubara yaitu Batubara-Batubara Petai (Seam C), Suban (Seam B), "Suban Marker", dan Manggus (Seam A); Anggota M3 mengandung 2 lapisan batubara yaitu Batubara-Batubara

Burung dan Benuang; sedangkan Angota M4 Anggota mengandung 4 lapisan batubara yaitu Batubara Kebon, Enim (EN), Jelawatan (J) dan Niru (N). 


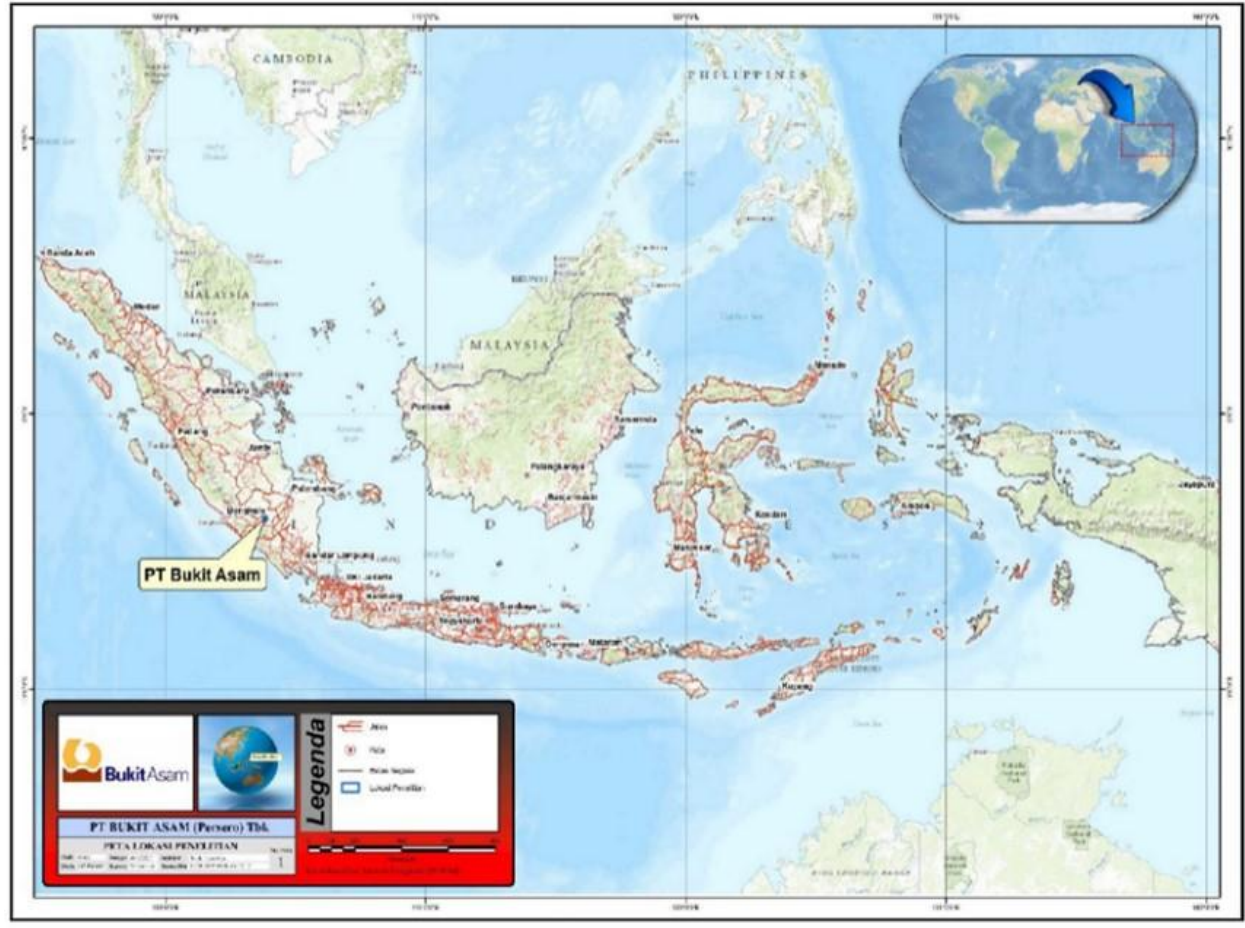

Gambar 1. Lokasi IUP UPTE-PTBA Secara Nasional

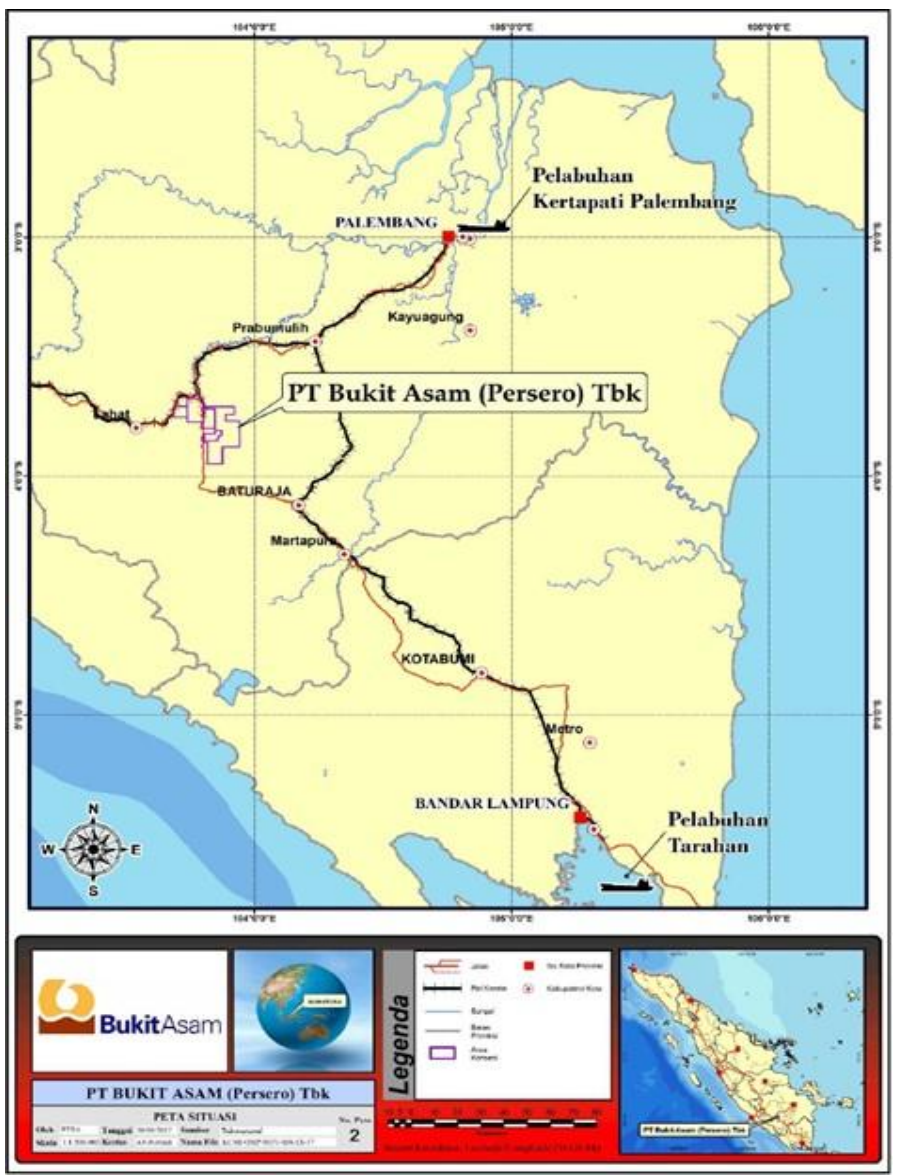

Gambar 2. Lokasi IUP-IUP UPTE-PTBA Secara Regional 


\section{KUALITAS BATUBARA IN-SITU}

Dalam kondisi normal, peringkat batubara di daerah Bukit Asam - Lahat dan sekitarnya bervariasi dari lignit hingga sub-bituminous. Pada beberapa area tertentu seperti Air Laya dan Bukit Kendi batubara tersebut mengalami pemanasan intrusi batuan beku yang mengakibatkan terjadi perubahan peringkat batubara dari sub bituminous menjadi bituminous dan bahkan antrasit. Perubahan peringkat tersebut mempengaruhi Nilai Kalori, Volatile Matter, dan Kadar Air pada batubara Bukit Asam. Pada umumnya peringkat batubaranya secara gradual meningkat dari wilayah yang jauh dari intrusi hingga yang mendekati intrusi.

Secara komposisi batubara Bukit Asam didominasi oleh maseral vitrinit. Berdasarkan sampel ply by ply, kandungan volume vitrinit bervariasi dari 56,6 hingga 98,2 \% dengan rata-rata 87,1\%; kandungan liptinit bervariasi dari 0,2 hingga $25,4 \%$ (rata-rata 5,3\%); serta kandungan inertinit bervariasi dari $<1 \%$ hingga $11,2 \%$ (rata-rata 3,8 \%). Secara megaskopis batubara Bukit Asam peringkat rendah mempunyai kilap yang umumnya kusam ("dull"), sedangkan batubara peringkat tinggi memperlihatkan kilap yang "bright".

Kandungan mineral matter dalam sampel bervariasi dari $<1 \%$ hingga $20 \%$ (rata-rata 3,4 \%). Data dari analisis batubara menunjukkan bahwa batubara Bukit Asam memiliki kadar abu yang rendah (umumnya kurang dari 10\%), serta kandungan sulfur yang juga rendah kecuali untuk beberapa lokasi Lapisan Batubara $\mathrm{C}$ dengan kandungan sulfur cukup tinggi. Walaupun Kadar Abu dan Kandungan Sulfur batubara Bukit Asam bervariasi secara spasial, namun kisaran nilainya sebagian besar masih berada pada rentang yang diterima dalam spesifikasi pemanfaatan batubara.

\section{E. PERBANDINGAN BIAYA PERAWATAN PERALATAN TAMBANG BERBASIS LITRIK DENGAN DIESEL}

Perawatan Unit PC 3000-6E dan Belaz-75135 pada penambangan elektrifikasi adalah sebagai berikut :

1) Pada Perjanjian Pengadaan Unit Shovel Listrik dan Jasa Kontrak Perawatan Penuh SPPH 3040, berdasarkan perjanjian tersebut maka perawatan dan ketersediaan spare part 7 unit PC3000-6E akan dijamin ketersediaannya oleh PT. United Tractors dengan jangka waktu 3 Tahun.

2) Pada Perjanjian Pengadaan Unit Dump Truck dan Jasa Kontrak Perawatan Penuh SPPH 3041, berdasarkan perjanjian tersebut maka perawatan dan ketersediaan spare part 40 unit Belaz-75135 akan dijamin ketersediaannya oleh PT Pusaka Bumi Transportasi dengan jangka waktu untuk 20 unit selama 2 tahun dan 20 unit selama 7 tahun.

Berikut adalah secara umum perbandingan biaya perawatan untuk peralatan penambangan elektrifikasi:

\section{PC 3000-6E VS PC 3000 Diesel}

a) PC 3000-6E (Electric) menggunakan motor listrik sebagai penggerak utama sehingga tidak dibutuhkan consumbale part pada engine drive (part engine dan engine oil) seperti halnya pada PC 3000 Diesel, sedangkan untuk kebutuhan consumable part lainnya sama.

b) Perbedaan konsumsi oli pada PC 3000 diesel dan PC 3000-6E listrik adalah Oli Engine, dengan konsumsi engine oil 0,8 ltr per jam (29.187 liter per tahun untuk 7 unit PC 3000-6E).

c) Waktu maintenance dan man hour shovel listrik lebih rendah $20 \%$ dibanding shovel diesel. 


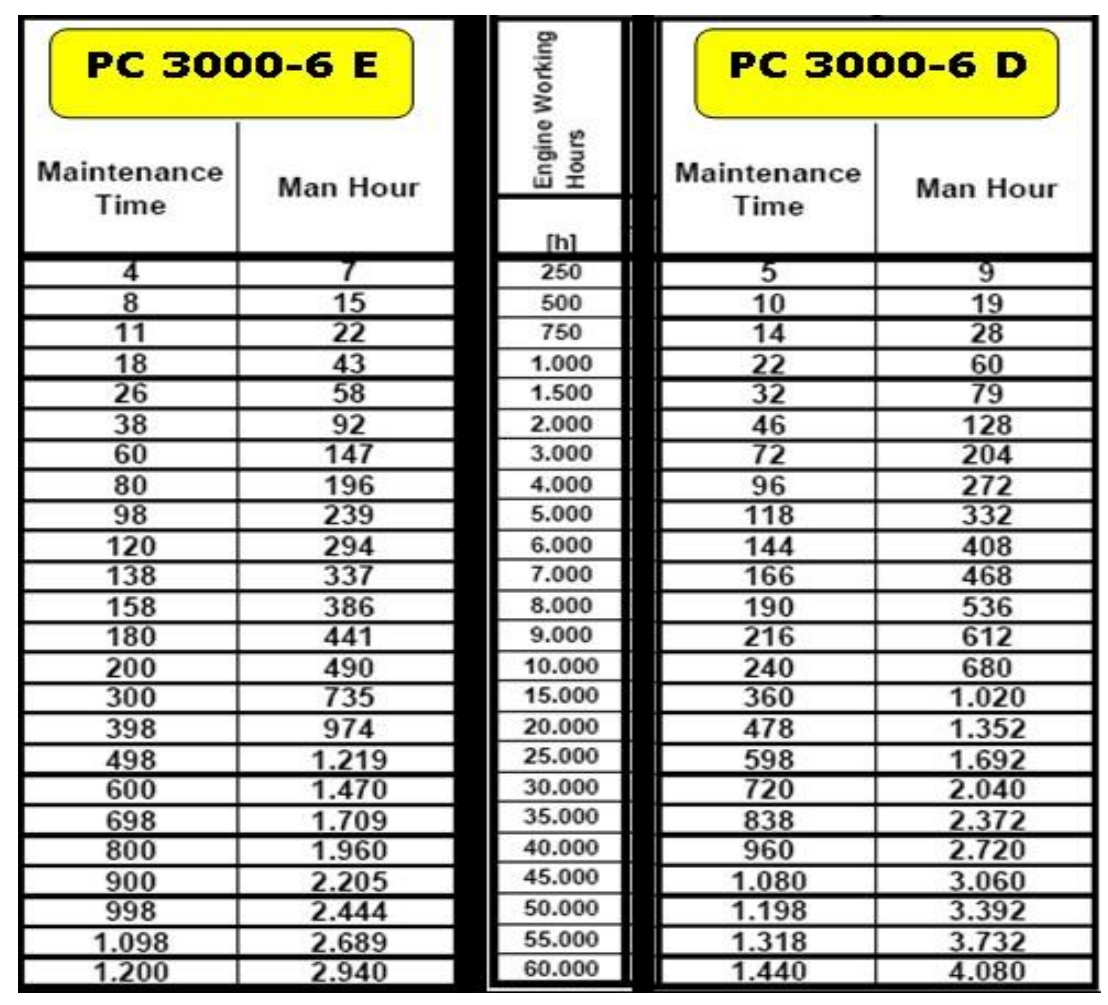

Gambar 3. Perbandingan maintenance time dan Man Hour antara PC 3000-6E dan PC 3000-6D

2. Belaz-75135 (electric drive) - Rigid Truck ( Mechanical Drive)

a) Dengan menggunakan electric Motor sebagai penggerak maka untuk Consumable Part untuk transmission dan differential (Part dan Oil ) tidak digunakan.

b) Penggunaan komponen / part pada electric drive menggunakan lebih sedikit gear dan bearing.

c) Penggunaan Lubrikasi (Oil \& Grease) pada electric drive dengan asumsi $50 \%$ lebih sedikit.

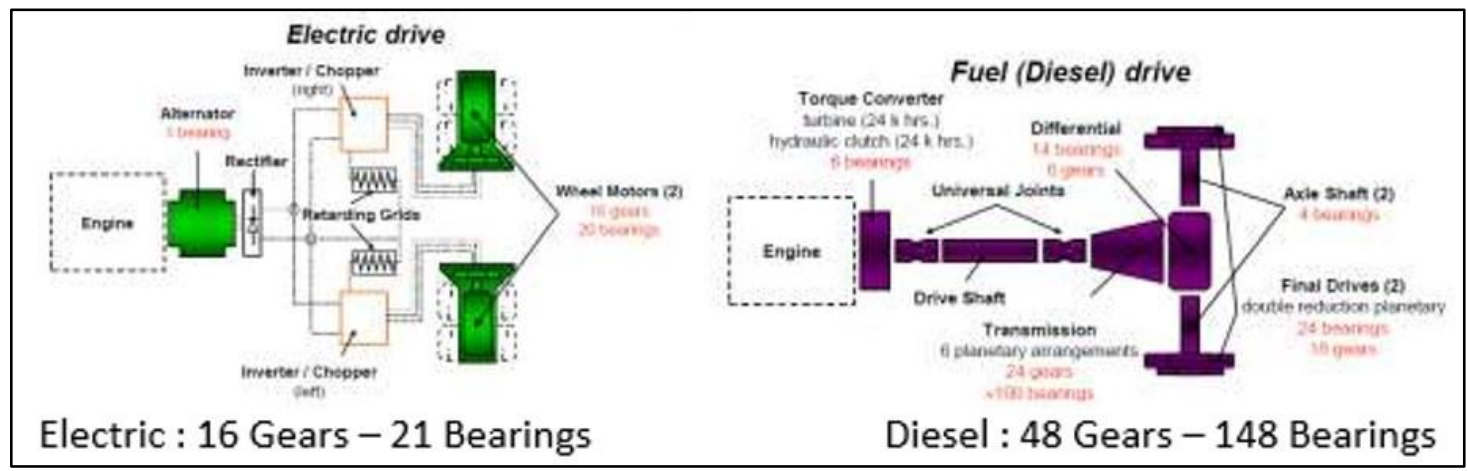

Gambar 4. Perbandingan Penggunaan Lubrikasi Belaz-75135 (electric drive) - Rigid Truck ( Mechanical Drive) 


\section{F. PERBANDINGAN PENGGUNAAN ENERGI}

\section{a. $\quad$ Shovel Listrik (PC 3000-6E)}

Dengan menggunakan 7 unit PC 3000-6E maka didapat keuntungan sebagai berikut:

a) Asumsi pengurangan penggunaan BBM sebanyak : 6,713,056.00 Lt/tahun

b) Asumsi Pengurangan emisi CO2 sebesar 3,385.7 CO2 (ton)

c) Penurunan biaya operasional (lebih efisien) serta tidak memerlukan stasiun pengisian BBM dan mobil tanki distribusi bahan bakar solar

\begin{tabular}{|c|c|c|c|c|c|c|c|}
\hline $\begin{array}{c}\text { PC3000-Electric } \\
\text { (Aktual) kWh/h }\end{array}$ & $\begin{array}{c}\text { Electric } \\
(\mathrm{Rp} / \mathrm{KWh})\end{array}$ & $\begin{array}{c}\text { Cost Electric } \\
\mathrm{Rp} / \mathrm{h}\end{array}$ & $\begin{array}{c}\mathrm{PC3000-Diesel} \\
\mathrm{Lt} / \mathrm{H}\end{array}$ & $\begin{array}{c}\text { Fuel } \\
(\mathrm{Rp} / \mathrm{Lt})\end{array}$ & $\begin{array}{c}\text { Cost Fuel } \\
\mathrm{Rp} / \mathrm{Lt}\end{array}$ & $\%$ & $\begin{array}{c}\text { Cost Saving } \\
\mathrm{Rp} / \mathrm{h}\end{array}$ \\
\hline 441.3 & 1240 & 547,212 & 184 & 8584 & $1,579,456$ & $189 \%$ & $1,032,244$ \\
\hline
\end{tabular}

\section{b. $\quad$ Rigid Dumptruck (Belaz-75135)}

Dengan menggunakan 40 unit Belaz 75135 maka didapat keuntungan sebagai berikut:

a) Asumsi pengurangan penggunaan $\mathrm{BBM}$ sebanyak : 4,628,256.00 Lt/tahun

b) Dengan asumsi pengurangan emisi CO2 sebesar 12,224.61 CO2 (ton)

c) Kapasitas Belaz 75135 yaitu 110 ton atau lebih besar $20 \%$ dibanding Rigid Truck Setara (90 ton)

\begin{tabular}{|c|c|c|c|c|c|c|c|}
\hline $\begin{array}{c}\text { Belaz-75135 } \\
\text { (Aktual) Lt/H }\end{array}$ & $\begin{array}{c}\text { Fuel } \\
\text { (Rp/tt) }\end{array}$ & $\begin{array}{c}\text { Cost Fuel } \\
\mathrm{Rp} / \mathrm{Lt}\end{array}$ & $\begin{array}{c}\mathrm{HD} 785 \\
\mathrm{Lt} / \mathrm{H}\end{array}$ & $\begin{array}{c}\text { Fuel } \\
(\mathrm{Rp} / \mathrm{Lt})\end{array}$ & $\begin{array}{c}\text { Cost Fuel } \\
\mathrm{Rp} / \mathrm{Lt}\end{array}$ & $\%$ & $\begin{array}{c}\text { Cost Saving } \\
\mathrm{Rp} / \mathrm{h}\end{array}$ \\
\hline 52.8 & 8584 & 453,235 & 75 & 8584 & 643,800 & $42 \%$ & 190,565 \\
\hline
\end{tabular}

\section{G. PERBANDINGAN PENGGUNAAN KONSUMSI OLI}

\section{a. $\quad$ Shovel Listrik (PC 3000-6E)}

Dari Handbook komatsu sebagai perbandingan dengan unit PC 3000 Diesel Komatsu didapat data oil consumption sebagai berkut:

\begin{tabular}{|c|c|c|c|c|c|c|c|c|c|c|}
\hline & \multicolumn{5}{|c|}{ Total Capacities Per Excavator } & \multicolumn{5}{|c|}{$\begin{array}{l}\text { Total Consumption Per Excavator } \\
\text { (Including oll change volume) }\end{array}$} \\
\hline & $\begin{array}{c}\text { Engine } \\
\text { Itr. } \\
\text { (US Gal) }\end{array}$ & $\begin{array}{l}\text { PTO } \\
\text { Itt. } \\
\text { (US Gal) }\end{array}$ & $\begin{array}{l}\text { Hydraulic } \\
\text { Reservoir } \\
\text { ltr. } \\
\text { (US Gal) }\end{array}$ & $\begin{array}{c}\text { Slew } \\
\text { gears } \\
\text { Itr. } \\
\text { (US Gal) }\end{array}$ & $\begin{array}{l}\text { Travel } \\
\text { gears } \\
\text { Itr. } \\
\text { (US Gal) }\end{array}$ & $\begin{array}{c}\text { Engine } \\
\text { Oil } \\
\text { ltr/h } \\
\text { (US Gal/h) }\end{array}$ & \begin{tabular}{|c|} 
Hydraulic \\
Oil \\
Itt/h \\
(US Gal/h)*
\end{tabular} & \begin{tabular}{|c|} 
Gear Oil \\
Ittr/h \\
$($ US Gal/h)**
\end{tabular} & $\begin{array}{c}\text { Central } \\
\text { Lubrication } \\
\mathrm{kg} / \mathrm{h}(\mathrm{lb} / \mathrm{h})\end{array}$ & $\begin{array}{l}\text { Slew ring } \\
\text { gear } \\
\text { Lubrication } \\
\mathrm{kg} / \mathrm{h}(\mathrm{lb} / \mathrm{h})\end{array}$ \\
\hline $\begin{array}{l}\text { PC3000 } \\
\text { SSA12V159 }\end{array}$ & $\begin{array}{c}190 \\
(50.2)\end{array}$ & $\begin{array}{c}90 \\
(23.8)\end{array}$ & $\begin{array}{l}2900 \\
(766)\end{array}$ & $\begin{array}{c}83 \\
(21.9)\end{array}$ & $\begin{array}{c}135 \\
(35.7)\end{array}$ & $\begin{array}{c}0.8 \\
(0.21)\end{array}$ & \begin{tabular}{|c|}
0.53 \\
$(0.14)$
\end{tabular} & $\begin{array}{c}0.10 \\
(0.026)\end{array}$ & $\begin{array}{c}0.14 \\
(0.31)\end{array}$ & $\begin{array}{l}0.035 \\
(0.08)\end{array}$ \\
\hline PC3000/E & - & $\begin{array}{c}90 \\
(23.8)\end{array}$ & $\begin{array}{l}2900 \\
(766)\end{array}$ & $\begin{array}{c}83 \\
(21.9)\end{array}$ & $\begin{array}{c}135 \\
(35.7)\end{array}$ & - & $\begin{array}{c}0.53 \\
(0.14)\end{array}$ & $\begin{array}{c}0.10 \\
(0.026)\end{array}$ & $\begin{array}{c}0.14 \\
(0.31)\end{array}$ & $\begin{array}{l}0.035 \\
(0.08)\end{array}$ \\
\hline
\end{tabular}

Dengan menggunakan PC 3000-6E maka didapat keuntungan sebagai berikut:

a) Dengan asumsi menggurangi penggunaan oil engine sebanyak $0.8 \times 7 \times 5212=\mathbf{2 9 , 1 8 7}$

liter per tahun

b) Dengan asumsi mengurangi limbah cair B3 sebanyak 29,187 liter per tahun

c) Penghematan biaya jasa pengiriman limbah cair B3 sebesar 29,187 liter 


\section{b. $\quad$ Rigid Dumptruck (Belaz 75135)}

Dari Handbook komatsu sebagai perbandingan dengan unit HD785 Komatsu didapat data fuel consumption sebagai berkut:

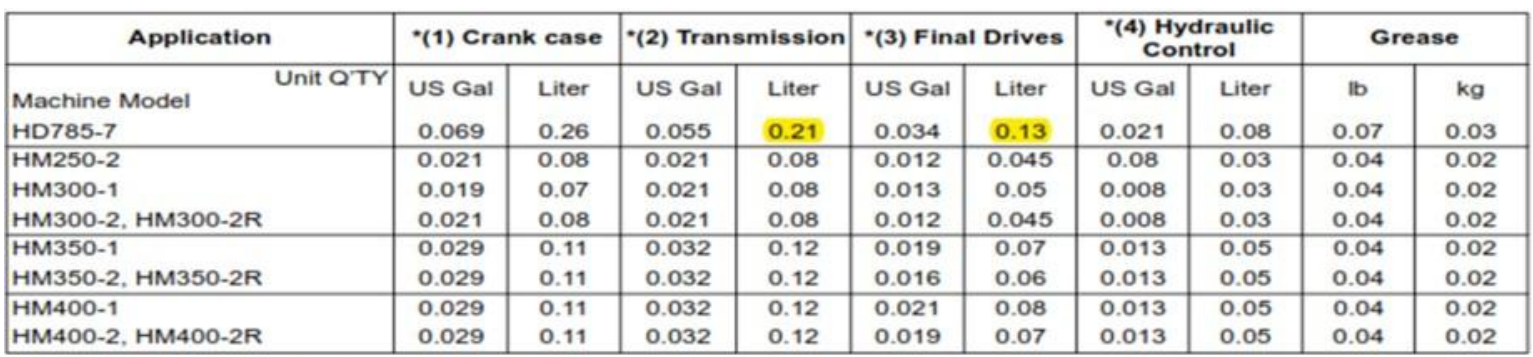

-(1) Includes lubricant oil of compressor for Portable Air Compressor

(2) Includes oils in the torque converter, main clutch and steering cases, differential, etc.

(3) Includes oils in the tandem case of Motor Grader

Includes oils in the differential case of Dump Truck

(4) Includes oils in the brake cooling tank

Dengan menggunakan 40 unit Belaz 75135 maka didapat keuntungan sebagai berikut:

a) Dengan asumsi menggurangi penggunaan oil engine sebanyak 0.34 x 40 x $5212=\mathbf{7 0 , 8 8 3}$

\section{liter per tahun}

b) Dengan asumsi mengurangi limbah cair B3 sebanyak 70,883 liter per tahun

c) Penghematan biaya jasa pengiriman limbah cair B3 sebesar 70,883 lt

\section{H. KELEBIHAN DAN KEKURANGAN PERALATAN TAMBANG BERBASIS LISTRIK}

a. Kelebihan \& Kekurangan Penggunaan PC 3000-6E Dari Segi Operasional

Dalam operasional shovel listrik (PC3000-6E) ada memiliki beberapa kelebihan dan kekurangan yaitu:

Kelebihan:

a) Produktifitas tinggi.

b) Dapat menggali dengan ketinggian bench maksimal 11 meter.

c) Memiliki Horse Power tinggi (1.206 HP) sehingga cocok dan handal dalam berproduksi secara maksimal (Hasil uji Lab PTBA diggability overburden rata-rata $1320 \mathrm{KPa}$ masuk kategori mudah digali)

d) Ground Pressure Unit SE PC3000-6E = $221 \mathrm{kPa}$,masih mampu didukung kondisi lapangan (hasil uji Lab PTBA ground pressure rata2 $685 \mathrm{kPa}$ )

e) Emisi gas CO2 dan Limbah cair B3 yang dihasilkan lebih sedikit.

Kekurangan/kendala:

a) Kurang fleksibel karena menggunakan rangkaian kabel $6 \mathrm{KV}$ di bagian belakangnya, sehingga memiliki keterbatasan manuver / pemindahan alat, harus hati hati.

b) Memerlukan prosedur khusus, pemandu shovel, cable lifting device dalam memindahkan rangkaian kabel

c) Hanya bisa beroperasi bila ada sumber power, sehingga dibutuhkan genset pada saat power mati.

b. Kelebihan \& Kekurangan Penggunaan BELAZ-75135 Dari Segi Operasional.

Dalam operasional Rigid Dump truck electric drive (BELAZ-75135) ada memiliki beberapa kelebihan dan kekurangan yaitu:

Kelebihan:

a) Memiliki kapasitas vessel lebih besar di kelasnya yaitu 110 ton,

b) Limbah cair B3 yang dihasilkan lebih sedikit. 
c) Ground Pressure Unit Belaz $620 \mathrm{kPa}$,masih mampu didukung kondisi lapangan (hasil uji Lab PTBA ground pressure rata2 $685 \mathrm{kPa}$ )

Kekurangan/kendala:

a) Belaz lebih berat sehingga dibutuhkan perawatan jalan dan front gali yang lebih banyak untuk meningkatkan produktivitas.

b) Harus lebih hati hati saat manuver di loading area.

\section{OPERASIONAL SHOVEL LISTRIK (PC 3000-6E)}

Operasional Shovel Listrik (PC 3000-6E) sebagai alat gali muat di Pit 2 dan Pit 3 pada lokasi IUP Banko Barat. Proses masuknya listrik dari jalur PLTU hingga ke unit shovel PC-3000E-6. Dimulai dari jalur umum upstream over head line (OHL) bertegangan $20 \mathrm{kv}$, dari Over Head Line (OHL), arus listrik diturunkan ke jalur downstream 20 kv menuju SSU (Switch Stop Unit) bertegangan 20 kv. SSU ini memiliki fungsi untuk mengambil jalur upstream OHL ke jalur downstream $20 \mathrm{kv}$ dan sebagai pengaman apabila terdapat trip di jalur setelah SSU.

Dari SSU arus listrik di alirkan menuju Ring. Ring berfungsi sebagai pembagi jalur $20 \mathrm{kv}$, dari 1 input $20 \mathrm{kv}$ menjadi 2 output $20 \mathrm{kv}$. Dari Ring, arus $20 \mathrm{kv}$ dialirkan menuju TSU (Transformator Switch Unit). Dari TSU tersebut, arus listrik $20 \mathrm{kv}$ diturunkan tegangannya menjadi $6 \mathrm{kv}$. Selain sebagai penurun tegangan dari $20 \mathrm{kv}$ ke $6 \mathrm{kv}$, TSU ini berfungsi sebagai pengaman apabila terjadi trip di jalur setelah TSU. Dari TSU, arus listrik 6 kv dialirkan ke CRU (Cable Reel Unit). CRU ini berfungsi sebagai roller cable dan sebagai pengaman pertama apabila terdapat trip dari Unit Shovel elektrik. Dari CRU, arus listrik dimasukkan ke unit shovel elektrik PC3000E-6.

Secara keseluruhan, jalur listrik dari OHL menuju ke unit shovel elektrifk diatas terdiri dari OHL (Upstream $20 \mathrm{kv}$ ) -> SSU (downstream $20 \mathrm{kv}$ ) -> Ring (Pembagi Arus) -> TSU (20 kv ke 6 kv) -> CRU (6 kv) menuju ke Unit Shovel Elektrik (6 kv). Diantara unit-unit jalur listrik tersebut, jalur kabel $20 \mathrm{kv}$ maupun $6 \mathrm{kv}$ dapat disambungkan dengan Junction Box (JB) untuk memperpanjang kabel menuju ke unit setelahnya. Secara system jalur diatas, jalur listrik shovel elektrik memiliki 3 rangkap proteksi, yaitu proteksi dari CRU, TSU dan SSU sebagai pengaman dari trip agar trip tidak berlanjut ke jalur Upstream.

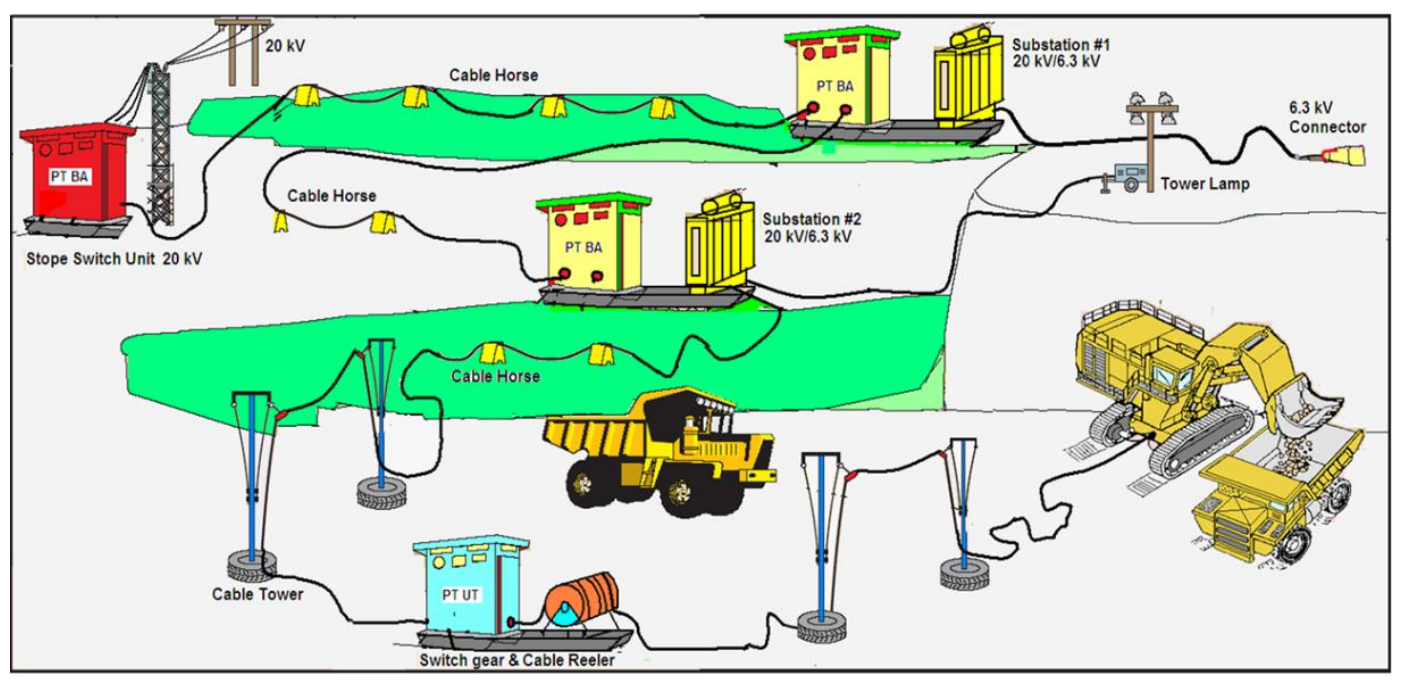

Gambar 5. Siklus Pendistribusian Listrik Shovel Listrik (PC 3000-6E) 


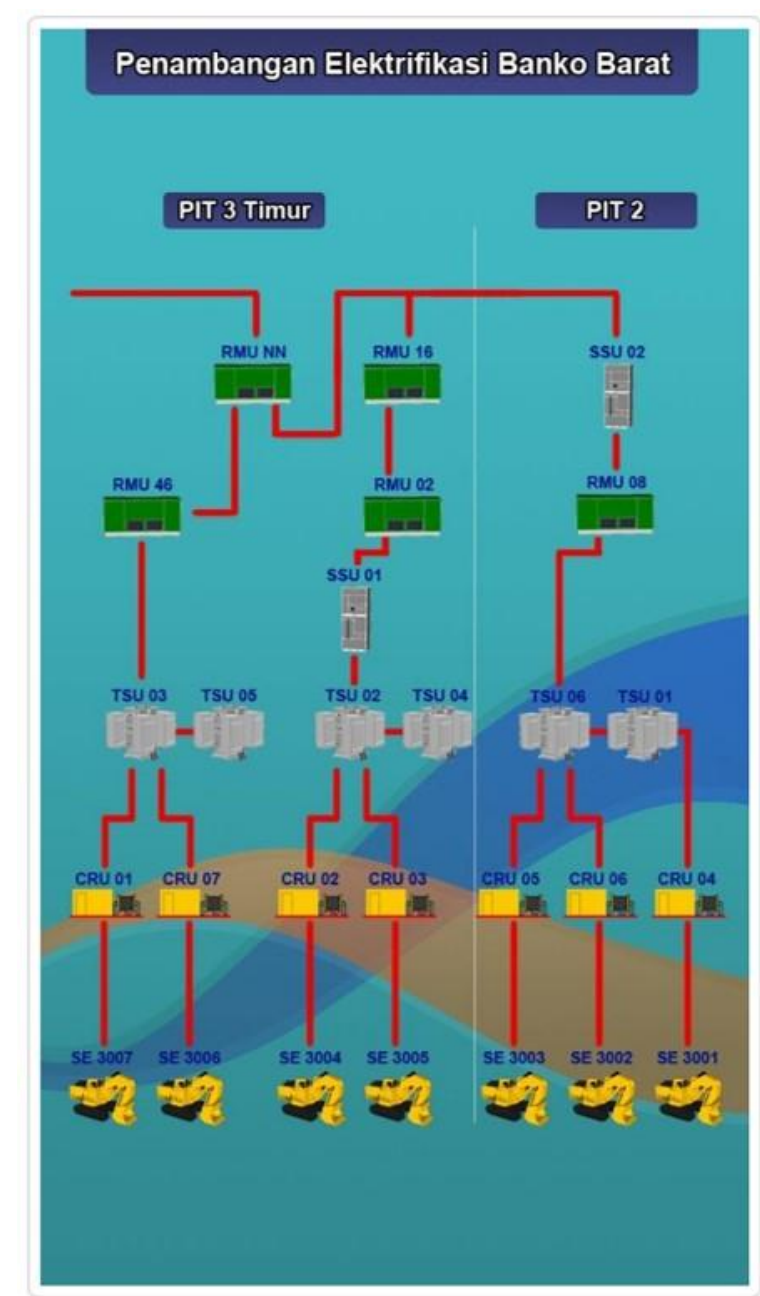

Gambar 6. Power Supply dan Distribusi Monitoring System

\section{J. MONITORING PRODUKSI}

Kegiatan monitoring operasioanl penambangan dan produksi dilakukan di Satuan Kerja Evaluasi dan Optimasi, adapun kegiatan operasional penambangan di monitor dengan menggunakan Fleet Management System (FMS) yang di pandu oleh Dispatcher. Adapun manfaat dari penggunaan Fleet Management System (FMS) ini yaitu :

1) Memberikan gambaran alokasi fleet Shovel Listrik (PC 3000-6E)

2) Menyediakan informasi posisi dan pergerakan equipment

3) Mencatat dan mengukur akuntabilitas waktu kerja dari equipment dan operator

4) Menyediakan informasi kesiapan equipment

5) Menyediakan informasi cycle time secara otomatis

6) Mencatat jenis material yang dibawa

7) Mencatat jumlah muatan yang diangkut dan dibawa

8) Melakukan Assignment Truck secara otomatis (Auto Dispatching)

9) Menyediakan laporan yang lengkap dan real-time

10) Membantu operator untuk meningkatkan produktifitas kerja

11) Meningkatkan koordinasi antara Dispatcher, Supervisor dan Operator

12) Membantu operator untuk mengurangi potensi kecelakaan 


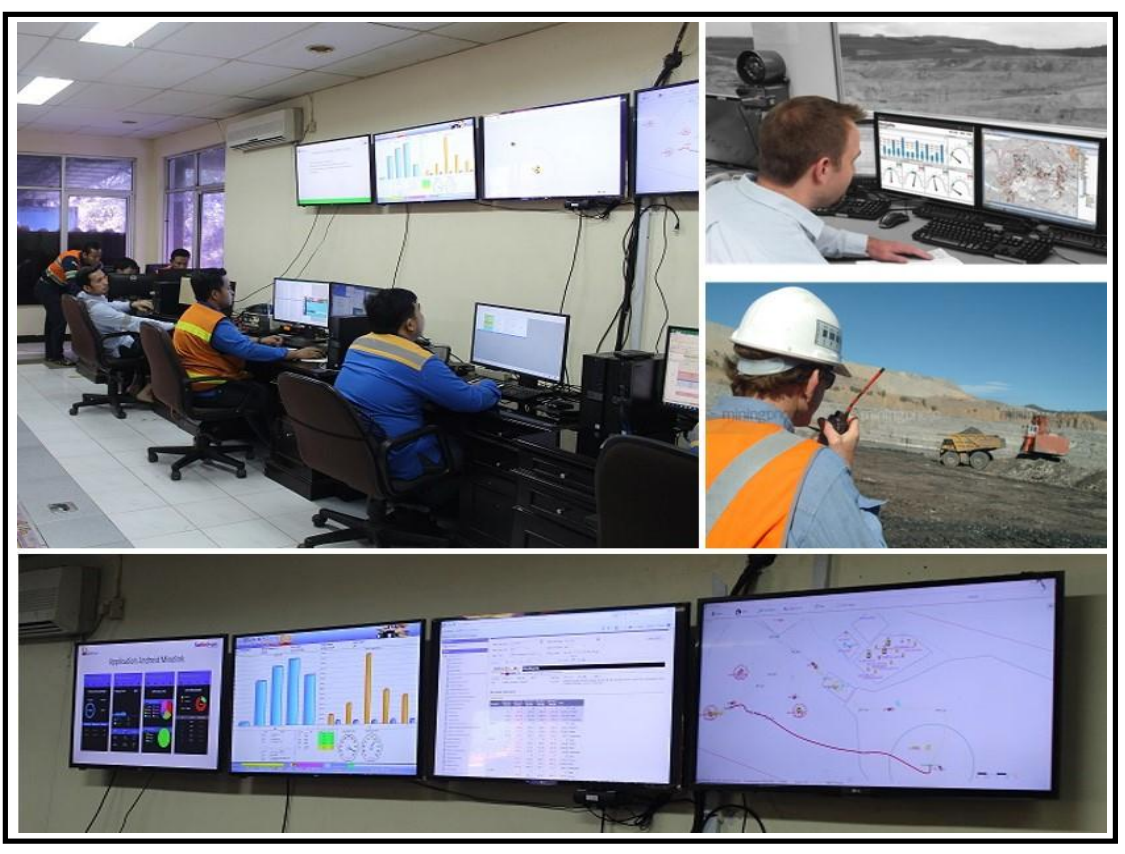

Gambar 7. Fleet Management System PT Bukit Asam, Tbk
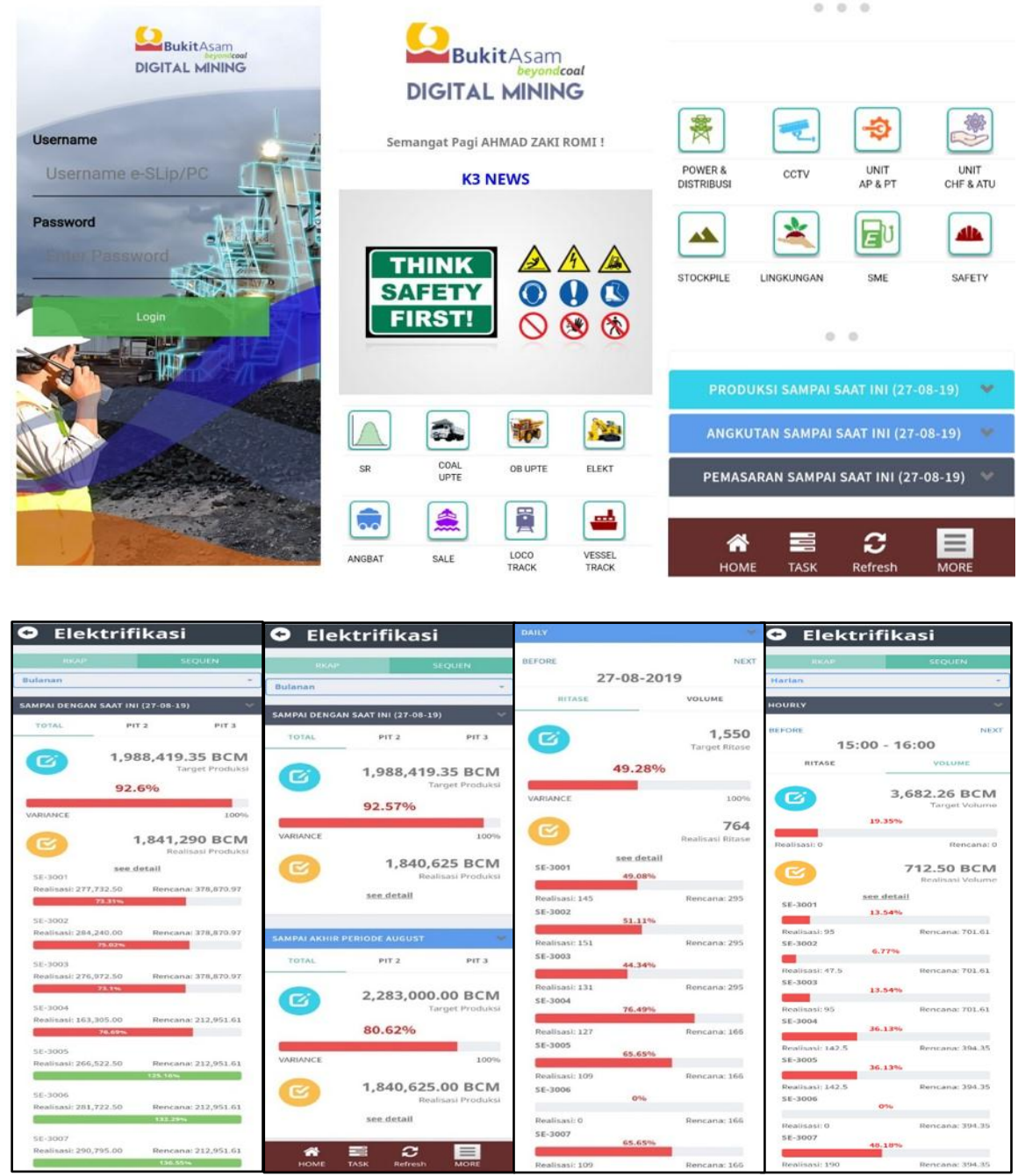

Gambar 8. Digital Mining PT Bukit Asam, Tbk 
Monitoring produksi dan evaluasi dilakukan secara real time data yang didapat melalui FMS yang di input di ruang dispatcher, dimana dispatcher juga berfungsi sebagai pusat komunikasi untuk monitoring kegiatan operasional penambangan. Data yang dihasilkan dari FMS sudah terintegrasi secara system dengan jaringan PT. Bukit Asam, Tbk, data produksi dapat di monitoring melalui mobile phone (HP) dimana Satuan Kerja Teknologi Informasi PTBA sudah membuat aplikasi untuk monitoring produksi secara real time. Sehingga dapat mempermudah bagi manajemen untuk memonitor ketercapaiana produksi secara real time dimana pun berada. 
PROSIDING TPT XXVIII PERHAPI 2019 